\title{
INTERNATIONAL JOURNAL OF

\section{THE ROLE OF THIRD PARTY SUPPORTED FOR DETERMINING CUSTOMERS ADOPTION OF INTERNET BANKING}

Alaa Ahmed Chyad Alkafagi*1, Ruslan Bin Romli², Ahmad Yusni Bin Bahaudin ${ }^{3}$, Jamal Mohammed Alekam ${ }^{4}$

${ }^{* 1,2,3,4}$ School of Technology Management \& Logistics, College of Business, Universiti Utara Malaysia, 06010, Sintok, Kedah, MALAYSIA

\section{Abstract:}

Definitely the Internet banking services adoption (IBSA) represents a good opportunity for developing nations to attain greater economic development and growth. This sector plays a vital role in developing numerous businesses and increasing Gross Domestic Product (GDP) in different countries, particularly in developing countries, such as the Republic of Iraq. Although a lot of research evidences the wide adoption of Internet banking in developed nations, there is still limited research in developing nations in the Middle East, specifically in Iraq on this area. There is definitely a need in this country to identify the factors that could encourage IBSA. There is also a paucity of empirical research on IBSA from the perspective of customers. Taking these into cognizance, this quantitative research aims to understand IBSA, by investigating the key factors that encourage customers to adopt Internet banking in the Iraqi context, using the Theory of Planned Behavior (TPB). In order to test this framework, a quantitative approach using the survey method is employed consisting of twenty eight (28) items with a seven-point Likert scale. Based on proportionate stratified random sampling, 535 out of 800 employees. For analysis purposes, Partial Least Squares-Structural Equation Modeling (PLS-SEM) was applied. Findings of this study reveal that all the research hypotheses are supported except one, namely subjective norms. This study found out there is high impact the role of third party support toward Internet banking services adoption among Iraqis customers.

Keywords:

Third party support, Internet Banking Services Adoption (IBSA), Middle East, Republic of Iraq.

Cite This Article: Alaa Ahmed Chyad Alkafagi, Ruslan Bin Romli, Ahmad Yusni Bin Bahaudin, Jamal Mohammed Alekam, "THE ROLE OF THIRD PARTY SUPPORTED FOR DETERMINING CUSTOMERS ADOPTION OF INTERNET BANKING” International Journal of Research - Granthaalayah, Vol. 3, No. 7(2015): 72-85.

\section{INTRODUCTION}

The availability and increase of new information and communication technologies (ICTs) in the financial industry has a significant impact on the way banks currently provide services to their customers (Hoehle et al., 2012). Around the world, banking remains the largest consumer of IT services, and the largest spender on IT systems. Many new business standards have been introduced, and these standards have a prominent role in changing the way that the banking 


\section{INTERNATIONAL JOURNAL OF RESEARCH -GRANTHAALAYAH \\ A knowledge Repository}

Management

industry functions. Internet technology, wireless technology and global straight-through processing (STP), have made it possible for the banking industry to move away from being mere physical banks to providing virtual services, allowing the banks to face global competition from other banks around the world, and to gain larger market shares, in order to satisfy the needs of customers (Sharma, 2009). These technological changes, new players in the banking arena, and globalization of business and service innovations, have led to intense market competition, and compelled banks to cater more to customers by providing them with a greater range of choices (Mansumitrchai \& Chiu, 2012; Alnsour \& Al-Hyari, 2011).

Technological developments have also availed opportunities for the banks and other service providers alike, to develop and offer customers greater flexibility, and more services, as consumers today are demanding better facilities and services (Tan \& Teo, 2000). According to Jalal, Marzooq, \& Nabi (2011), Internet banking has been growing significantly, and has a direct impact on the way businesses are conducted.

However, Internet banking adoption by customers remains a complex, elusive, yet extremely vital phenomenon (Hoehle et al., 2012). Indeed, there is no doubt that internet banking services adoption (IBSA) represents the opportunities for developing nations to leap forward towards greater economic development and growth, where the creation of added value is driven by information, knowledge, and the adoption of ICTs.

A critical review of past studies (2000-2011) in this perspective has however revealed that majority of these studies only investigated intention to adopt internet banking (Tan \& Teo, 2000; Shih \& Fang, 2004 \& Hernandez \& Mazzon, 2007), while most others also compared adopters and non-adopters (Sathye, 1999; Suganthi et al., 2001; Gerrard and Gumingham, 2003; Akinci et al., 2004; Chan \& Lu, 2004; Laforet \& Li, 2005; Lee et al., Gerrard et al., 2006; Awamleh \& Fernandez, 2006; Polasik \& Winsniewski, 2009 \& Foon \& Fah, 2011), instead of investigating actual users of internet banking (Hong et al., 2013). Hong et al. (2013) in this view affirms that " Without a good understanding about the adopters of Internet banking, it would be challenging to understand the contributing factors that will cause the Internet banking adopters continue to adopt Internet banking ". Therefore, the internet banking studies should focus on actual users or adopters instead of people who just have the "intention to adopt". On the other hand, measuring of internet banking adoption can only be effective when the actual users of internet banking have reached a critical mass (Tan \& Teo, 2000; Chan \& Lu, 2004).

Foreign and Iraqi businessmen and bank customers have been stating their dissatisfaction about the weak electronic banking services in Iraq (US Department of Defense, 2010; Albaghdadia, 2011; Mohsen, 2010). Besides, the Central Bank of Iraq (CBI) has been seeking to reduce the use of cash in the country because of geographical challenges and security issues, which make the transfer of money across the country difficult and risky. Hence the goal of internet banking in Iraq is to mainly automate the settlement of checks and salaries, activate electronic cards and Internet banking activities in order to keep more liquidity in bank accounts and avoid the obstacles to move large blocks of money (CBI, 2013). 


\section{INTERNATIONAL JOURNAL OF RESEARCH -GRANTHAALAYAH \\ A knowledge Repository}

Management

The declining role of third party support causing in low adoption of internet banking in Iraq is lack and the declining role of the social influence (Al-hammadany \& Heshmati, 2011a, p. 70; Shendy, 2011 p.17). For instance, when banks advertise their services through daily and weekly newspaper and other medium, there is every tendency that the customers could be influenced. However, the influence of family members, friends, and colleagues at work can also be of great influence but evidence has shown that these social factors are lacking as the majority of Iraqis are not actively involved in the usage of internet banking. It is therefore essential to investigate the influence of social norms on the adoption of internet banking among Iraqis especially that this construct has not been tested empirically in Iraq.

\section{LITERATURE REVIEW}

The TPB extends TRA by incorporating other variables that either make behavior to be difficult or ease to perform. This extension was meant to explain the limitation of TRA in dealing with behavior since a person has incomplete volitional control over behavior (Ajzen, 1991, p. 181). The proposition of TPB is that two factors of attitude and subjective norm determine behavioral intention. In addition, PBC was also added so to take care of circumstances where an individual may be lacking total control over her or his behavior (Ajzen, 1985; Ajzen \& Madden, 1986). $\mathrm{PBC}$ has been proved by previous studies to have significant impact on behavioral intention and actual behavior. This is indicated in Figure 1. Moreover PBC can have a direct or interactive effect on behavior (through behavioral intention).

In this respect therefore, Ajzen (1991) is of the opinion that there are circumstances where behavioral intention may slightly vary from actual behavior; therefore, PBC should have the power to predict of behavior independently. Even though PBC and behavioral intentions are significant predictors of actual behavior, in some particular conditions, there is tendency that one predictor may be significant than the other predictor. Therefore, where behavioral prediction of intentions is likely to be accountable by actual or deliberate intentions, PBC should be able to directly predict behavior and facilitate the implementation of behavioral intentions into behavior (Armitage \& Conner, 2001). As a result, PBC and behavioral intention, can be used directly or indirectly to predict actual behavior.

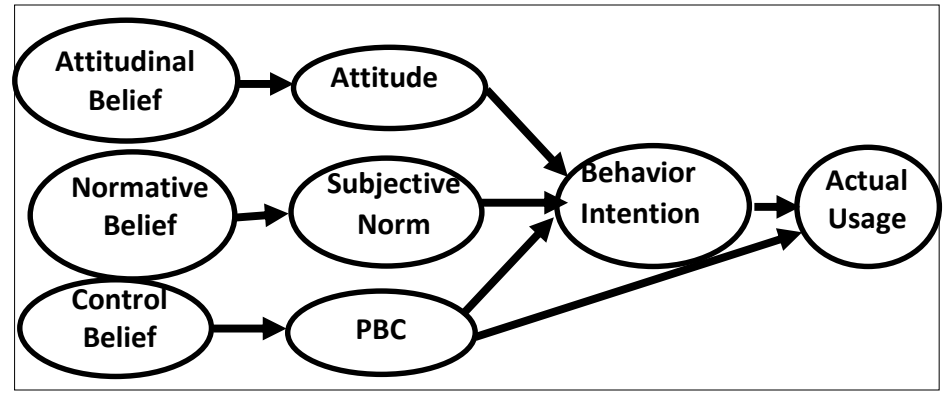

Figure 1: TPB (Ajzen, 1991) 


\section{INTERNATIONAL JOURNAL OF RESEARCH -GRANTHAALAYAH \\ A knowledge Repository}

Management

TPB has been widely applied in various studies of technology acceptance. In particular, it has used successfully in the prediction of IBSA. For example, the study of OK and Shon (2010) that was conducted in Korea revealed that behavioral intention was not influenced by attitude, subjective norm, and $\mathrm{PBC}$, and but was influenced by normative belief structures, attitudinal belief structures, and control belief structures. Both TBP and TRA predict behavioral intention to use the IBS well with TBP having some empirical merits over TRA. In addition, Shih \& Fang (2004) extended TPB model in order to examine those factors that influence behavioral intention of 425 banking customers in Taiwan to adopt IBS. The outcome of the study reveals that attitude is significant in the prediction of intention while PBC and subjective norm are not. Further, Yaghoubi and Bahmani (2011) conducted their study among 349 Iranians using TPB and the outcome of their study reveals that controlling the risk of IBS is more significant than providing benefits; on the other hand, it is very robust in predicting customers' intentions to use such services.

Ajzen and Fishbein (1980, p.82) defined Actual Behavior as: "The individual's observable response in a given situation with respect to a given target; behavior is a function of compatible intentions ". In addition, IBSA is defined by Kim and Prabhakar (2012, P. 538) as: "The client's usage of multiple services represented in carrying out banking transactions over the Internet, including balance inquiry, account transfer, and many other services that are basically carried out online".

IBS is extremely beneficial to customers: customers can execute their bank transactions or contact their banks faster, at any time and from anywhere, 24 hours a day. It does not require the physical interaction with the bank, and customers can avoid long queues and restrictive business hours, lower transaction costs, quick responses to complaints, more service variety and improved services quality (Mansumitrchai \& Chiu, 2012; Alnsour\& Al-Hyari, 2011;Nasri, 2011; Al-Somali et al., 2009; Shi et al., 2008; Mattsson \& Helmersson, 2005;Pikkarainen et al. 2004). Customers also do not have to be put on hold for telephone banking services; all these benefits make for easier banking (Karjaluoto, Mattila \& Pento, 2002).

The aim of this study to investigate and measure the influence of third party support in IBS setting generally those could influence on the behavior of customers toward IBSA.

Iraqi citizens are unaware of the benefits that technology can bring, besides, there is limited empirical study on TPB in Middle East (Al-Majaly, 2011, p. 39), specifically in Arab countries like Iraq.

\section{RESEARCH MODEL}

The research framework proposed in this study is not exactly the same as the TPB model as shown in Fig. 2. We have added direct relationships from attitude and subjective norms to IBSA, which is not in TPB original model. The new components in the framework will be: Third party 


\section{INTERNATIONAL JOURNAL OF RESEARCH -GRANTHAALAYAH \\ A knowledge Repository}

Management

support in term of social recommendation and prestigious media influences. In addition, three components from TPB (attitude (ATT), subjective norm (SN), and Perceived behaviour control $(\mathrm{PBC}))$.
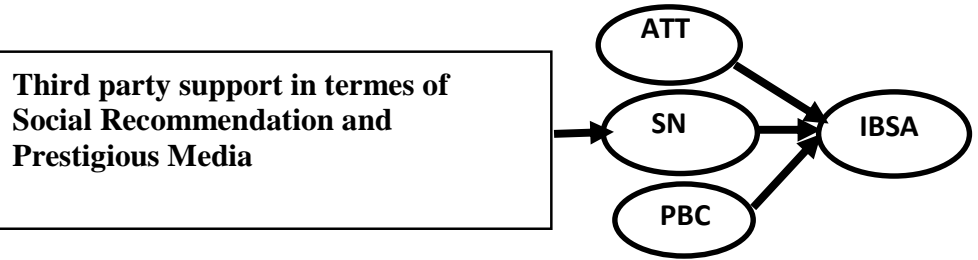

Figure 2: Framework Model

An attitude towards adopting an innovation is derived from an individual's beliefs that adopting the innovation will lead to certain consequences (Ajzen \& Fishbein, 1980). It indicates an individual's positive or negative evaluations about performing the behavior. Ajzen (1991) advocates that attitude is a product of belief about a behavior and the individual's evaluation of the outcome resulting from that behavior.

Only a few past studies found that attitude is a more accurate predictor of behavior than behavioral intention (Bentler\& Speckart, 1979; Albrecht \& Carpenter, 1976). The influence of attitude on the individual's behavior to use information technology has been theorized and validated by some studies (AL-Majali \& Mat, 2010b; Shi et al., 2008; Martinez Guerrero et al., 2007; Ndubisi \& Sinti, 2006; Karjaluoto et al., 2002). Based on the finding have found by Ibrahim (2012), the variables that affect the behavioural intention can also be tested as the factors that affect the actual usage behavior. However, most prior studies were conducted outside the Middle East countries, and not much was done in Iraq. Therefore, this study intends to fill this gap by examining customer's attitude toward IBSA in TPB theory in the Iraqi context. Based on the previous discussions, the conceptual relationship between attitude and IBSA is positive. Given that, the researcher hypothesizes that:

H1: Attitude has significantly and positively influences IBSA.

Subjective norm refers to an individual's perceptions of the social pressure to engage in a certain behavior. The idea suggests that attitudes and beliefs of others in groups to which an individual belongs will shape his or her behavior toward the usage of a specific technology (Ajzen 1991). Even though TRA, TPB and DTPB models have discussed subjective norm as one of the precursors of behavior intention (Taylor \& Todd, 1995; Ajzen, 1991; Ajzen \& Fishben, 1975) very limited studies used the single models of subjective norm in their studies (AL-majali \& Mat, 2010b; Shi et al., 2008; Duda et al., 2007; Hernandez \& Mazoon, 2007). For instance Shi et al., (2008) revealed that subjective norm is a significant variable that has influence on IBSA and help bankers to help drive more customers through influence of friends, colleagues and family members to embrace IBSA. Additionally, the study of Hernandez (2007) reveals that IBSA is 


\section{INTERNATIONAL JOURNAL OF RESEARCH -GRANTHAALAYAH \\ A knowledge Repository}

Management

significantly influenced by subjective norm. Also, in a study conducted by Rouibah's (2008) in Kuwait with respect to adoption of instant messages service online among working adult of organizations, it was discovered that subjective norm positively affect the behaviors of workers in this area. The findings of Al-Majali \& Mat (2010b) also align with others when the study found that subjective norm significant and positive influence toward IBSA using TPB. However, there is no study conducted in Iraq related to IBSA settings to examine this relationship. Given that, the researcher hypothesizes that:

$\mathrm{H} 2$ : Subjective norm, significantly and positively influences on IBSA.

The tenet of TPB is that user's behavioral intention is influenced by his/her PBC (Ajzen, 1991). This is premised on the fact that an individual is likely to engage in a certain behavior when he/she believes that the required resources to perform the behavior are available. In this view, the empirical study of Al-majali and Mat (2010b) found that PBC significantly and positively influences IBSA among Jordanians towards IBSA. Several studies in different contexts that are different from IBS setting have investigated direct effect of PBC on actual behavior (Gopi \& Ramayah, 2007; Fusilier \& Durlabhji, 2005; Pedersen \& Nysveen, 2004; George, 2004). This therefore shows that the influence of PBC on IBSA has not been sufficiently investigated (Shih \& Fang, 2004; Tan \& Teo, 2000). Based on this discussion, this study aims to test this linkage in IBSA. The following hypothesis is proposed:

H3: Perceived behavior controlling significantly and positively influences IBSA.

An innovation create uncertainty (Rogers, 1995). Individuals tend to be uncomfortable with uncertainty and try to increase interaction with a third party to interpret the innovation (Karahanna et al., 1999). This increased interaction influences the behavioral decision (Nilsson, 2007; Karahanna et al, 1999). Informational influence occurs when relevant others of the individual inform of their own personal experience and evaluation of the innovation or when the individual can observe the relevant others using the innovation.

Social recommendation is defined in this research as all potential online consumers' family members, friends, and colleagues ' support and assurance of a certain internet banking transaction (Nor \& Pearson, 2008. Many referral sets, such as peers and superiors, have been determined by researchers, as having the ability to create social stress on a person regarding the usage of computers (Taylor \& Todd, 1995). In terms of a consumer-oriented service, the consumer-relevant groups around the individual (family, friend, etc.) may influence the individual's adoption. Zhou \& Tian (2010) conducted a study to investigate what factors contribute to consumers' trusting beliefs in online shopping in a relatively low-trust environment. College students in China were used as sample for this study. The finding of this study revealed that perceived reference power (previous customers, social recommendations and referrals from prestigious media) is an influential antecedent to the trusting beliefs of consumers.

According to Zhou and Tian (2010, p.153), prestigious media includes well-known business magazines, newspapers, etc. $\mathrm{Ng} \&$ Rahim (2005, p. 239) defined this factor as "The influence or pressures from the prestigious media to perform the behavior and included mediums of 


\section{INTERNATIONAL JOURNAL OF RESEARCH -GRANTHAALAYAH \\ A knowledge Repository}

Management

communication, such as newspapers, radio, television, Internet, broadcast e-mails, official announcements made by authorities, etc., that are designed to reach the mass of the people". Prestigious media is considered one of the main information sources in many fields, due to their coverage of wide areas and promotional campaigns that attract people's attention and promote the activities from which the community may get benefits (Agostinelli \& Grube, 2002; Zhou \& Tian, 2010). The researcher will thus investigate and test the influence of the third party support dimension in terms of social recommendation and prestigious media upon the individuals' behavior concerning IBSA in Iraq. Moreover, this dimension's influence has been investigated in fragmented and diverse ways in the IT field in general (Alshammari \& Mohd, 2012; Zhou \& Tian, 2010), not specifically in the IBS area .The conceptual relationship between third party support and subjective norm is positive based on previous studies and past literature . Thus, this study hypothesizes a positive relationship as follows:

H4: Third party support in terms of social recommendation and prestigious media has significantly and positively influence subjective norm.

\section{METHODOLOGY}

The researcher uses quantitative research to collect the required data, the sample used from staff of public universities in Iraq. They have been chosen as the respondents of this study. Only five hundred and thirty five (535) questionnaires were useful for purpose of analysis. Direct delivery of the survey questionnaire to participants was preferred as opposed to using online or postal surveys because the postal system in Iraq is not reliable. The respondents 'demographic factors were gathered to collect information about each respondent that participated in the survey. The questions were designed for the respondents to choose their answers. Most of the respondents that participated in the survey were males $62.4 \%$, and only $37.6 \%$ of the females.

The survey measures 5 constructs, which are: third party support in terms of social recommendation and prestigious media influence, attitude, subjective norm, PBC, and IBSA. All these variables are adopted or adapted from previous studies. The following is a summary of the instrument that will be used to measure all variables and its source with the coefficient alpha:

1. IBSA- by four items from Raman et al., (2008).

2. Attitude- by five items from nor and Pearson (2008).

3. Subjective norm - by five items from nor and Pearson (2008).

4. PBC- by four items from Shih and Fang (2004).

5. Third party support in terms of social recommendation influence and prestigious media- by ten items (three items from Shih and Fang (2004), two items from nor and Pearson (2008), and five items from $\mathrm{Ng} \&$ Rahim (2005).

\section{ANALYSIS OF RESULTS}

The technique of partial least-squares (PLS) analysis, an implementation of structural equation modeling (SEM), was applied to test the measurement model to determine the internal consistency reliability and construct validity of the multiple items scales used to operationalize 


\section{INTERNATIONAL JOURNAL OF RESEARCH -GRANTHAALAYAH \\ A knowledge Repository}

Management

the study variables. As shown in Table 1, all reliability measures were well above the recommended level of 0.70 as an indicator for adequate internal consistency (Hair etal., 1995; Nunnally, 1978).

The results of this analysis is used to accept or reject the hypotheses based on the significance of the standardized path coefficient beta weight $(\beta)$ which illustrates how strong is the relationships among constructs. The (R2) value, which shows the amount of variance explained by independent variables. Both, (R2) and path coefficients indicate that how well the model is performing. (R2) shows the predictive power of the model and the value should be interpreted in the same way as (R2) in regression analysis. The path coefficients should be significant and consistent with expectations (Chwelos et al., 2001). To be able to conclude whether the path coefficients were statistically significant or not, this study applied the bootstrapping techniques embedded with the SmartPLS2.0.

\begin{tabular}{|c|c|c|c|c|}
\hline $\begin{array}{l}\text { Const } \\
\text { ructs }\end{array}$ & $\begin{array}{l}\text { Ite } \\
\text { ms }\end{array}$ & Loading & $\begin{array}{l}\text { Cronbach } \\
\text { s Alpha }\end{array}$ & AVE \\
\hline \multirow[t]{4}{*}{ ATT } & $\begin{array}{l}\text { ATT } \\
2\end{array}$ & 0.625 & 0.727 & \\
\hline & $\begin{array}{l}\text { ATT } \\
3\end{array}$ & 0.726 & & \\
\hline & $\begin{array}{l}\text { ATT } \\
4\end{array}$ & 0.867 & & \\
\hline & $\begin{array}{l}\text { ATT } \\
5\end{array}$ & 0.745 & & \\
\hline \multirow[t]{4}{*}{ IBSA } & $\begin{array}{l}\text { IBS } \\
\text { A1 }\end{array}$ & 0.880 & 0.748 & 0.582 \\
\hline & $\begin{array}{l}\text { IBS } \\
\text { A2 }\end{array}$ & 0.865 & & \\
\hline & $\begin{array}{l}\text { IBS } \\
\mathrm{A} 3\end{array}$ & 0.501 & & \\
\hline & $\begin{array}{l}\text { IBS } \\
\text { A4 }\end{array}$ & 0.763 & & \\
\hline \multirow[t]{3}{*}{ PBC } & $\begin{array}{l}\text { PBC } \\
1 \\
\end{array}$ & 0.758 & 0.891 & \\
\hline & $\begin{array}{l}\mathrm{PBC} \\
2\end{array}$ & 0.896 & & \\
\hline & $\begin{array}{l}\text { PBC } \\
3\end{array}$ & 0.915 & & \\
\hline
\end{tabular}

\begin{tabular}{|c|c|c|c|c|}
\hline & $\begin{array}{l}\text { PBC } \\
4\end{array}$ & 0.902 & & \\
\hline \multirow[t]{4}{*}{ SN } & SN1 & 0.792 & 0.859 & \\
\hline & $\mathrm{SN} 2$ & 0.891 & & \\
\hline & $\mathrm{SN}_{3}$ & 0.842 & & \\
\hline & SN4 & 0.753 & & \\
\hline \multirow{10}{*}{$\begin{array}{l}\text { Third } \\
\text { party }\end{array}$} & TP1 & 0.792 & 0.899 & 0.758 \\
\hline & $\mathrm{TP2}$ & 0.834 & & \\
\hline & TP3 & 0.894 & & \\
\hline & TP4 & 0.885 & & \\
\hline & TP5 & 0.796 & & \\
\hline & TP6 & 0.889 & & \\
\hline & TP7 & 0.885 & & \\
\hline & TP8 & 0.919 & & \\
\hline & TP9 & 0.535 & & \\
\hline & $\begin{array}{l}\text { TP1 } \\
0\end{array}$ & 0.866 & & \\
\hline
\end{tabular}

The standardized path coefficient of 0.619 seems to indicate that attitude have a positive and statistically significant effect on IBSA and at 0.01 level of significance $(\beta=0.619, t=12.730, p$ $<0.01$ ), hence the H1 is supported. On the other hand, the standardized path coefficient of -0.151 suggests that subjective norm has negatively and statistically significant effect on IBSA and at 0.01 level of significance $(\beta=-0.151, \mathrm{t}=3.736, \mathrm{p}<0.01)$, hence $\mathrm{H} 2$ is unsupported. The result showed that perceived behavior control has a positive influence and statistically significant effect on customers' adoption of Internet banking $(\beta=0.099, \mathrm{t}=2.911, \mathrm{p}<0.01)$, hence $\mathrm{H} 3$ is 


\section{INTERNATIONAL JOURNAL OF RESEARCH -GRANTHAALAYAH \\ A knowledge Repository}

Management

supported. Third party support terms of social recommendation and prestigious media has positive influence and significant impact on subjective norm toward of IBSA $(\beta=0.646, t$ $=16.535, \mathrm{p}<0.01$ ), hence $\mathrm{H} 4$ is supported. All these results show in Table2.

Table 2: Hypotheses Testing Results and Assessment of the structural model

\begin{tabular}{|c|c|c|c|c|c|}
\hline $\mathrm{H}$ & $\beta$ & (STERR) & $\mathrm{T}$ & Pvalue & Result \\
\hline 1- $\quad$ ATT $>$ IBSA & 0.619354 & 0.047743 & 12.730733 & 0.000 & yes \\
\hline & & & & $* * *$ & \\
\hline $2-\quad$ SN $\rightarrow$ IBSA & -0.151236 & 0.040478 & 3.736227 & 0.000 & No \\
\hline & & & & $8 * *$ & \\
\hline 3- $\quad$ PBC $\rightarrow$ IBSA & 0.099879 & 0.034304 & 2.911612 & 0.002 & yes \\
\hline & & & & $8 * *$ & \\
\hline 4- $\quad$ TP $\rightarrow$ SN & 0.646946 & 0.039126 & 16.535058 & $\begin{array}{l}0.000 \\
8 * *\end{array}$ & Yes \\
\hline
\end{tabular}

\section{DISCUSSION AND CONCLUSION}

The main aim of this study to investigate and identify the factors that would encourage customer to adopt internet banking in Iraq and evaluate the role of third party support in terms of social recommendation and prestigious media, this study uses TPB model to measure of variables in internet banking setting. This study applied partial least squares structural equation modelling (PLS-SEM) as the major analysis technique as well as SPSS, since PLS SEM is a relatively new analytical technique in construction. As shown in Table 2, the hypotheses (H1, H3, H4) were statistically supported by the findings of the study, while hypotheses of, $\mathrm{H} 2$ was not supported.

The result shows asserts that third party support in terms of social recommendation and prestigious media have high a significant control over decisions to adopt internet banking because respect and modesty among Iraqis is important since this country follow the Arab cultures, it plays an important role in influencing customers to adopt this technology.

\section{REFERENCES}

[1] Ajzen, I. (1991). The theory of planned behavior. Organizational behavior and human decision processes, 50(2), 179-211.

[2] Akinci, S., Aksoy, S. and Atilgan, E. (2004). Adoption of internet banking among sophisticated consumer segments in an advanced developing country, International Journal of Bank Marketing, 22(3), 212-32.

[3] Albaghdadia. (2011, November 7).Researcher calls for private banks to develop marketing mechanisms. Available: http://www.albaghdadianews.com/economy/item/482-bagv-ndinaklzhaej-akgazh\%D8\%A9-kbznne-oknab-akbyonnj.html [Accessed: Oct, 2014]. 


\section{INTERNATIONAL JOURNAL OF RESEARCH -GRANTHAALAYAH \\ A knowledge Repository}

Management

[4] Al-Hammadany, F. H., \& Heshmati, A. (2011a). Determinants of Internet Use in Iraq. International Journal of Communication, 5(2011), 1967-1989.

[5] Al-majali, M. M., \& Mat, N. K. N. (2010b). Applications of planned behavior theory on internet banking services adoption in Jordan: Structural equation modeling approach. ChinaUSA Business Review, 9(12), 1-12.

[6] Al-majali, M., \& Mat, N. K. N. (2011). Modeling the antecedents of internet banking service adoption (IBSA) in Jordan: A structural equation modelling (SEM) approach. Journal of Internet Banking and Commerce, 16(1), 1-15.

[7] Al-majali, M. (2011). The Use of Theory Reasoned of Action to Study Information Technology in Jordan. Journal of Internet Banking and Commerce, 16(2), 1-11.

[8] Alnsour, M., \& Al-Hyari, K. (2011). Internet Banking and Jordanian Corporate Customers: Issues of Security and Trust. Journal of Internet Banking and Commerce, 16(1), 1-14.

[9] Alshammari, S. \& Mohd, H. (2012).Introducing and Validating Factors Affecting Potential Netizens' Perceptions toward the Interpersonal Trusting Beliefs of a Trustee in B2C $e$ Commerce within the Malaysian Context. International Journal of e-Education, e-Business, $e$ Management and e-Learning, 2(3), 1-5.

[10]Al-Somali, S. A., Gholami, R., \& Clegg, B. (2009). An investigation into the acceptance of online banking in Saudi Arabia. Technovation, 29(2), 130-141.

[11] Anderson, J.C., \& Gerbing, D.W. (1988). Structural equation modeling in practice: A review and recommended two-step approach. Psychological bulletin, 103(3), 411.

[12] Awamleh, R., \& Fernandes, C. (2006). Diffusion of Internet banking amongst educated consumers in high income non-OECD country. Journal of International Banking and Commerce, $11(3)$.

CBI (2013). Payment System. Retrieved on 15 April 2013 from: http://www.cbi.iq/index.php?pid=PaymentSystems\&lang=en

[13] Celik, H. (2008). What determines Turkish customers' acceptance of internet banking? International Journal of Bank Marketing, 26(5), 353-370.

[14] Chan, S. C., \& Lu, M. T. (2004). Understanding internet banking adoption and use behavior: a Hong Kong perspective. Journal of Global Information Management (JGIM), 12(3), 21-43.

[15] Chu, P., \& Wu, T. (2004). Factors influencing tax-payer information usage behaviour:

Test of an integrated model. International Journal of the Information Systems for Logistics and Management. 1(1), 27-37.

[16] Chwelos, P., Benbasat, I., \& Dexter, A. S. (2001). Research report: empirical test of an EDI adoption model. Information systems research, 12(3), 304-321.

[17] Dauda, Y., Santhapparaj, A., Asirvatham, D., \& Raman, M. (2007). The Impact of E commerce Security, and National Environment on Consumer adoption of Internet Banking in Malaysia and Singapore. Journal of Internet Banking and Commerce, 12(2), 1-20.

[18] Foon, S. Y., \& Fah, Y. C. (2011). Internet banking adoption in Kuala Lumpur: an application of UTAUT model. International Journal of Business and Management, 6(4), 161167.

[19] Fornell, C., \& Larcker, D.F. (1981). Evaluating structural equation models with unobservable variables and measurement error. Journal of marketing research, 39-50. 


\section{INTERNATIONAL JOURNAL OF RESEARCH -GRANTHAALAYAH \\ A knowledge Repository}

Management

[20] Fornell, C., \& Bookstein, F.L. (1982). Two structural equation models: LISREL and PLS applied to consumer exit-voice theory. Journal of Marketing research, 440-452

[21] Fornell, C., Lorange, P., \& Roos, J. (1990). The cooperative venture formation process: A latent variable structural modeling approach. Management Science, 36(10), 1246-1255.

[22] Frankfort-Nachmias, C. \& Nachmias, D. (1996). Research Methods in the Social Sciences, 5th ed. St. Martin's Press: London.

[23] Fusilier, M., \& Durlabhji, S. (2005). An exploration of student internet use in India: the technology acceptance model and the theory of planned behaviour. Campus-Wide Information Systems, 22(4), 233-246.

[24] George, J. F. (2004). The theory of planned behavior and Internet purchasing. Internet research, 14(3), 198-212.

[25] Gerrard, P., Cunningham, J., \& Devlin, J. (2006). Why consumers are not using internet banking: a qualitative study. Journal of Services Marketing, 20(3), 160-168.

[26] Gerrard, P., \& Cunningham, J. B. (2003). The diffusion of Internet banking among Singapore consumers. International Journal of Bank Marketing, 21(1), 16-28

[27] Gopi, M., \& Ramayah, T. (2007). Applicability of theory of planned behavior in predicting intention to trade online: some evidence from a developing country. International Journal of Emerging Markets, 2(4), 348-360.

[28] Hair, J. F., Jr., Anderson, R. E., Tatham, R. L. and Black, W. C.(1995) Multivariate Data Analysis, 3rd ed, Macmillan Publishing Company, New York.

[29] Hernandez, J. M. C., \& Mazzon, J. A. (2007). Adoption of internet banking: proposition and implementation of an integrated methodology approach. International Journal of Bank Marketing, 25(2), 72-88.

[30] Hoehle, H., Scornavacca, E., \& Huff, S. (2012). Three decades of research on consumer adoption and utilization of electronic banking channels: A literature analysis. Decision Support Systems. 1-11.

[31] Hong,Y.,Teh, B., Vinayan, G.,Soh, C., Khan,N., \& Ong,T.(2013). Investigating the Factors Influence Adoption of Internet Banking in Malaysia: Adopters Perspective.International Journal of Business and Management; 19(8), 24-31.

[32] Jalal, A., Marzooq, J., \& Nabi, H. A. (2011). Evaluating the Impacts of Online Banking Factors on Motivating the Process of E-banking. Journal of Management and Sustainability, 1(1), 1-32.

[33] Karahanna, E., Straub, D. W., \& Chervany, N. L. (1999). Information technology adoption across time: a cross-sectional comparison of pre-adoption and post-adoption belief. Mis Quarterly, 23(2), 183-213.

[34] Laforet, S., \& Li, X. (2005). Consumers' attitudes towards online and mobile banking in China. International Journal of Bank Marketing, 23(5), 362-380.

[35] Lau, A. S. (2002). Strategies to motivate brokers adopting on-line trading in Hong Kong financial market. Review of Pacific Basin Financial Markets and Policies, 5(04), 471-489.

[36] Lee, M. C. (2009). Factors influencing the adoption of internet banking: An integration of TAM and TPB with perceived risk and perceived benefit. Electronic Commerce Research and Applications, 8(3), 130-141. 


\section{INTERNATIONAL JOURNAL OF RESEARCH -GRANTHAALAYAH \\ A knowledge Repository}

Management

[37] Lim, K. H., Aia, C. L., Lee, M. K. \& Benbasat, I. (2006). Do I Trust You Online, and If So, Will I Buy? An Empirical Study of Two Trust-Building Strategies. Journal of Management Information Systems, 23(2), 233-266.

[38] Lohmoller, J.B. (1989). Latent variable path modeling with partial least squares: PhysicaVerlag Heidelberg.

[39] Mahdi, M. O. S. (2011). Trust and security of electronic banking services in Saudi commercial banks: Saudis versus Non Saudis opinions. African Journal of Business Management, 5(14), 5524-5535.

[40] Mansumitrchai, $S \&$ Chiu, C. (2012). Adoption of internet banking in UAE: Factors Underlying Adoption Characteristics. International Journal of management and marketing Research, 5(1), 103-115.

[41] Mohesr (2012). Minister of higher Education Science and Research. Public Universities. Retrieved on 10/10/2012 from: http://www.mohesr.gov.iq/PageViewer.aspx?id=16

[42] Mohsen, A. (2010).Factors influencing the customer's choice of electronic banking, a study in a sample of customers Iraqi banks. Mustansiriya University, pp.1-16, Available at: http://www.shatharat.net/vb/showthread.php?t=11857 [accessed 3 July 2011]

[43] Ng, B. Y. \& Rahim, M. A., (2005). A socio-behavioural study of home computer users' intention to practice security. Proceedings of the Ninth Pacific Asia Conference on Information Systems, 234-247, 7 - 10 July Bangkok, Thailand, 2005.Retrived on 5,Jan., 2012 from : http://www.pacis-net.org/file/2005/255.pdf

[44] Nilsson, D. (2007). Internet banking and the impact of seller support and third party. Journal of Internet Banking and Commerce, 12(1).1-9.

[45] Nor, K. M., \& Pearson, J. M. (2008). An exploratory study into the adoption of internet banking in a developing country: Malaysia. Journal of Internet Commerce, 7(1), 29-73.

[46] Nunnally, J.C., \& Bernstein, I.H. (1994). Psychometric theory. McGraw, New York.

[47] Ok, S. J., \& Shon, J. H. (2006). The determinant of internet banking usage behavior in Korea: a comparison of two theoretical models.1-15. http://citeseerx.ist.psu.edu/viewdoc/download?doi=10.1.1.97.3786\&rep=repl \&type $=p d f$

[48] Pedersen, P., \& Nysveen, H., (2004). Using the theory of planned behaviour to explain teenagers' adoption of text messaging services. Working Paper, Agder University College, July, 14, 2005,1-36. Retrived on 10, March, 2012 from: http://mdfoo.s3.amazonaws.com/brijsingh/175547709709bb988bf8259830528e25/10.1.1.20.224 2.pdf

[49] Polasik, M., \& Wisniewski, P. T. (2009). Empirical analysis of Internet banking in Poland. International Journal of Bank Marketing, 27(1), 32-52.

[50] Raman, M., Stephenaus, R., Alam, N., \& Kuppusamy, M. (2008). Information Technology in Malaysia: E-service quality and Uptake of Internet banking.Journal of Internet Banking and Commerce, 13(2), 1-18.

[51] Rogers, E. M. (1995). Diffusion of Innovations (4th Ed). The Free Press.

[52] Sharma, D. (2009). India's Leapfrogging Steps from Bricks-and-Mortar to Virtual Banking: Prospects and Perils. The IUP Journal of Management Research, 8(3), 45-61.

[53] Sathye,M.(1999). Adoption of internet banking by Australian consumers: an empirical Investigation. International Journal of Bank Marketing, 17(7), 324-334. 


\section{INTERNATIONAL JOURNAL OF RESEARCH -GRANTHAALAYAH \\ A knowledge Repository}

Management

[54] Shendi, A. (2011). Patterns and electronic banking options Acceptance and rejection, College of Business and Economics- University of Wasit, Prof. Dr. Adib Qasim Shendi. Retrieved on 11 March 2012 from: www.iasj.net/iasj?func=fulltext\&aId=53361.

[55] Shi, W., Shambare, N., \& Wang, J. (2008). The adoption of internet banking: An institutional theory perspective. Journal of Financial Services Marketing, 12(4), 272-286.

[56] Shih, Y. Y., \& Fang, K. (2004). The use of a decomposed theory of planned behavior to study Internet banking in Taiwan. Internet Research, 14(3), 213-223.

[57] Sugathi, B., \& Balachandran. (2001). Internet banking patronage: an empirical investigation of Malaysia.Journal of Internet Banking and Commerce, 6(1).

[58] Tan, M., \& Teo, T. (2000). Factors influencing the adoption of Internet banking. Journal of the Association for Information Sciences, 1(5), 1-42.

[59] Taylor, S., \& Todd, P. A. (1995). Understanding information technology usage: A test of competing models. Information systems research, 6(2), 144-176.

[60] US Department of Defense (2010). Soldiers Bring Electronic Banking to Iraq. Jan. 11, 2010. Retrieved on 10/10/2012 from: http://www.defense.gov/news/newsarticle.aspx?id=57446.

[61] Woon, I. M., \& Kankanhalli, A. (2007). Investigation of IS professionals' intention to practise secure development of applications. International journal of human-computer studies, 65(1), 29-41.

[62] Zhou, M., \& Tian, D. (2010). An integrated model of influential antecedents of online shopping initial trust: empirical evidence in a low-trust environment. Journal of International Consumer Marketing, 22(2), 147-167.

\section{APPENDICES}

APPENDIX A: Measurement Scale of Constructs

\section{IBSA}

1- I find internet banking is useful for managing my financial matters.

2- I believe internet banking is an easy way to conduct banking activities.

3- I find that internet banking is encouraging.

4- I feel fast internet access speed is important in internet banking

\section{Attitude}

1-Using Internet banking is a good idea.

2-I like the idea of using internet banking.

3-Using internet is a pleasant idea.

4-Using internet banking is an appealing idea.

5-Using internet banking is an exciting idea.

\section{Subjective Norm (SN)}

1-People who influence my behavior think that I should use internet banking.

2-People who are important to me think that I should use internet banking.

3-People whose opinions I value think I should use internet banking.

4-People who are close to me think that I should use internet banking.

5-People who influence my decisions think that I should use internet banking. 


\section{INTERNATIONAL JOURNAL OF RESEARCH -GRANTHAALAYAH \\ A knowledge Repository}

Management

\section{Percived Behavior control (PBC)}

1 - I would be able to operate internet banking.

2- I have the resources to use internet banking.

3- I have the knowledge to use internet banking.

4- I have the ability to use internet banking.

\section{Third party support}

1. I will use the Internet banking because my family, friends, or colleagues used it.

2. I will have to use the Internet banking if my family, friends, or colleagues already had used it.

3. I have to use the Internet banking because my family, friends, or colleagues thought I should use it.

4- My family, friends, or colleagues who are important to me would think that using Internet banking is a wise idea.

5. My family, friends, or colleagues who are important to me would think that using Internet banking is a good idea.

Prestigious media influence

6- The prestigious media suggest that I should use the internet banking regularly within the forthcoming month

7- Prestigious media reports influence me to use internet banking regularly within the forthcoming month

8- I feel under pressure from the prestigious media to use internet banking services regularly within the forthcoming month.

9- Prestigious media is full of reports, articles and news suggesting using internet banking services is a good idea.

10- Prestigious media and advertising consistently recommend using internet banking services

Corresponding Author: ALAA AHMED CHYAD ALKAFAGI, School of Technology Management \& Logistics, Universiti Utara Malaysia, Kedah, 06010, Malaysia; alaco_75@yahoo.com. B50, 15, 5 U-Garden Condo.PRS1 Gelugor 11700, Penang, Malaysia 